CHAPTER TWELVE

SIDDHI AND MAHĀSIDDHI IN EARLY HAṬHAYOGA

\author{
James Mallinson
}

In a forthcoming monograph on pre-modern hathayoga and its practitioners ${ }^{1}$ I identify a corpus of Sanskrit texts on early hathayoga, ${ }^{2}$ texts which are the sources for early hathayoga's syncretic systematization into the classical hațayoga of the Hathapradipika. ${ }^{3}$ In this article I shall examine the treatment in those works of siddhis, the supernatural powers which arise either directly or indirectly as a result of the practice of yoga or tantric rites. ${ }^{4}$

The oldest traditions of hațayoga are informed by tantric yoga, both Śaiva and Pāñcarātrika, and traditions of brahmanical yoga found in, for example, the original Skandapurana and the Mārkandeyapurāna. ${ }^{5}$ In a secondary stage of its development hathayoga was appropriated by practitioners in the traditions of Western Transmission (Paścimāmnāya) and, subsequently, Southern Transmission (Dakșināmnāya) Kaula Śaivism. ${ }^{6}$ It is this Kaula-influenced form of

\footnotetext{
${ }^{1}$ James Mallinson, Yoga and Yogis: The Texts, Techniques and Practitioners of Traditional Hațayoga (forthcoming).

2 These works are the Amṛtasiddhi, Dattātreyayogaśāstra, Gorakșaśataka, Vivekamārtanda, Khecarìvidyā, Yogabija, Amaraughaprabodha and Śivasaṃitā. To these may be added the Amaraughaśăsana, which, although not used to compile it, is likely to predate the Hathapradīpika and teaches variants of the practices classified therein as mudrās, practices which set hațhayoga apart from other varieties of yoga. There is one text not written in Sanskrit which teaches the hațhayogic mudrās and predates the Hațhapradīpikā: the Old Marāțhī Jñāneśvarī, on which see Catherine Kiehnle, "The Secret of the Nāths: The Ascent of Kundulalinī according to Jñāneśvarī 6.151-328," Bulletin des Etudes Indiennes 22-23 (2005): 447-494.

${ }^{3}$ The Hathapradīpika can be dated to approximately 1450 CE (Christian Bouy, Les Nätha-Yogin et les Upanișads [Paris: Diffusion de Boccard, 1994], 81-85).

${ }_{4}$ They can also arise as a result of birth, herbal preparations or asceticism: janm aușadhimantratapaḥsamādhijāh siddhayaḥ (Yogasūtra 4.1).

${ }_{5}$ These oldest traditions of hathayoga are found in the Amrtasiddhi and Dattātreyayogaśāstra.

6 The Western Transmission appropriation is evinced by the Gorakșaśataka, Vivekamārtanda and Khecarìvidyā; that of the Southern Transmission (or at least its later reformation) by the Śivasaṃhitā.
} 
hațhayoga, with its subtle physiology of Kunḍalinī's ascent through the cakras, which became its dominant paradigm.

Kaula Śaivism is a late manifestation and reformation of the siddhioriented Śaivism of the Mantramārga, which, "though it accommodates the quest for liberation, is essentially concerned with the quest for supernatural experience." "This 'supernatural experience' takes the form of both the attainment of siddhis and the enjoyment of otherworldly pleasures (bhoga). ${ }^{8}$

In its earliest manifestations, hathayoga was the preserve of the mumuksu, the seeker of liberation (moksa), rather than the bubhuksu, the seeker of enjoyment (bhoga). After its appropriation by various Kaula traditions, hathayoga incorporated their subtle physiology but did away with their complex and exclusive bhoga-oriented systems of initiation, mantras and mandalas, together with the direct quest for siddhis. Texts on hathayoga from the period of its appropriation by the heirs of the Kaulas betray a heightened preoccupation with siddhis but this is absent in its subsequent classical reformation in texts such as the fifteenth-century Hathapradip $i k \bar{a}$ and the seventeenth-century Hatharatnāvalì.

\section{InTENTIONAL AND UnINTENTIONAL SIDDHIS}

Only two texts in the corpus of Sanskrit works on early hathayoga, the Dattātreyayogaśästra and the Yogabija, voice explicitly the understanding of siddhis which is implicit throughout most of the corpus. In the Dattātreyayogaśästra the many powerful siddhis which arise in the second of hathayoga's four avasthās or 'stages', the ghațāvasthā, are said to be obstacles to mahāsiddhi, 'the great siddhi, and the wise yogi is instructed not to delight in his powers, nor to show them to anyone else. He should behave like a fool in order to keep his powers hidden; if not he will attract a large number of disciples, busy with whom he will neglect his practice and become absorbed in worldly concerns. ${ }^{9}$ The Yogabija distinguishes between two types of siddhi:

\footnotetext{
7 Alexis Sanderson, "Śaivism and the Tantric Traditions," in The World's Religions, ed. S. Sutherland, L. Houlden, P. Clarke and F. Hardy (London: Routledge, 1988), 660-704, 667.

8 Ibid., 664.

9 This is a paraphrase of Dattātreyayogaśāstra 193-197. The exact same sentiment was expressed to me by a Dasnāmī Nāgā Samnyāsī of the Jūnā Akhārāa in 2006 when I asked him in the course of an interview at his kuțiya in Chauntra, Kangra District,
} 
kalpitā and akalpitā, 'intentional' and 'unintentional'. Intentional siddhis are sought deliberately and are achieved by means of alchemy, herbs, mantras, the body and so forth. They are impermanent and of little potency. The same siddhis occur spontaneously, but unintentionally, in the master yogi, in which case they are permanent and very powerful. These spontaneous siddhis have no purpose; they simply signify one who has mastered yoga and are signs on the path to mokșa like the many tìrthas seen by pilgrims on the way to Kāsí. One can identify a perfected master, liberated while living, by the attainment of such siddhis. ${ }^{10}$

The attitude towards siddhis made clear in the Dattātreyayogaśästra reflects that found in the Yogasütra, namely that siddhis are obstacles to the goal of yoga practice. ${ }^{11}$ In the Yogasütra, however, explicit instructions are given on how to achieve the various siddhis. If the yogi wants divine hearing, for example, he should practice samyama on the relationship between hearing and the ether (3.41). Intentional siddhis of this sort are not taught in mainstream hațhayogic texts. ${ }^{12}$

The lack of importance given to siddhis in the majority of the texts of hațhayoga results in their akalpitā variety not always being distinguished from trivial or even undesirable by-products of practice, particularly in its early stages. Thus at Amaraughaśāsana 9.2, Kunḍalinī’s ascent of the central channel is said to bring about trembling and fainting as well as the ability to attract and see distant objects. In the Dattātreyayogaśāstra, the perfection of unassisted breath retention (kevala kumbhaka) means that nothing in the three worlds is difficult to attain. Increasing durations of its practice result in, in sequence, sweating, trembling, jumping about like a frog (dardurī), leaving the

Himachal Pradesh, whether he thought it was possible for yogis to fly. This part of the interview can be seen at http://www.youtube.com/watch?v=p5jWGRn3t8c. The yogis of the Jūnā Akhārāan, whose iștadevatā is Dattātreya, are direct heirs of the yoga tradition of the Dattātreyayogaśāstra.

${ }_{10}$ This is a paraphrase of Yogabija 173c-182d. For descriptions of akalpitā siddhis achieved in the course of the practice of hațhayoga, see e.g. Yogabija 164a-170b, Khecarīvidyā 2.106a-110b, Amaraughaśāsana 10.33-37, Jñāneśvarī 6.259-270, 6.296298.

${ }^{11}$ Yogasūtra 3.37: te samādhau upasargā vyutthāne siddhayaḥ|. See Hara 1999 on similarly anti-siddhi stances taken by the Buddha and Pāśupatas.

12 One exception to this is the practice of the elemental dhäranās, in which concentration on an element leads to its conquest and concomitant siddhis (see e.g. Dattātreyayogaśāstra 221-242, Vivekamārtanda 132-140 = [Nowotny, Gorakșaśataka 153-161]). These dhäranās are stages in a type of layayoga in which the elements and other tattvas are sequentially resorbed into the supreme element. 
ground ${ }^{13}$ indifference to eating a lot or a little, diminished excretions and sleep, the absence of worms, slobber, sweat and bad odors in the body, strength, power over terrestrial animals (bhücarasiddhi) and, finally, becoming as handsome as the god of love. ${ }^{14}$ The Vivekamārtanda says that there are three levels of prānāyanma, low, middle and high, resulting respectively in the body becoming hot, trembling and rising upwards (86-87 ( = Nowotny Gorakșaśataka 107)).

Identifying what constitutes a hathayogic siddhi is made more difficult by the ambiguity of the word siddhi itself, which in hathayogic works is more often used to mean 'success' than 'supernatural power'. Śivasamhitā 3.19-20, for example, teaches the seven signs of siddhi. In hathayogic works the eight classical siddhis ${ }^{15}$ are called gunas, not siddhis. ${ }^{16}$ Thus, apart from those few instances where siddhis are explicitly identified, there are no criteria by which to draw a line between the relatively mundane benefits of yogic practice (e.g. increased digestive fire) ${ }^{17}$ and those that are more impressive (e.g. the ability to eat nothing or huge amounts of food with equal indifference). ${ }^{18}$ Rather than attempt either to define a hațhayogic siddhi or to give a comprehensive enumeration and typology of the benefits of yogic practice as described in all the texts of early hat hayoga (which would be prohibitively long and for the most part unenlightening), I shall examine their treatment in just two works of the corpus, the Amrtasiddhi and the Sivasamhita. . Not only will this give an overview of the types of sid-

13 'Leaving the ground' (bhūmityāga) is not necessarily beneficial, or even fun. Lāl Jì Bhāī, a yogi I met in Rishikesh in 1997, reported that often when meditating while practicing khecarimudrā he would involuntarily fly across the room, which would occasionally result in his jațā becoming caught in his fan.

${ }^{14}$ Dattātreyayogaśästra 146-165. This final side-effect, becoming as handsome as the god of love, has the deleterious result of women lusting after the yogi; he must carefully guard against wasting his bindu.

15 Yogasūtrabhāsya ad 3.45.

16 Dattātreyayogaśāstra 245, 254; Vivekamārtanda 129, 155 ( = Nowotny Gorakșaśataka 150, 178); Khecarīvidyā 2.109, 3.6; Amaraughaprabodha 43; Śivasaṃhitā 3.90, 4.108, 5.57, 5.106, 5.179, 5.207; Hathapradīpikā 3.126. In the śaivāgama too guna is the preferred name for the eight classical powers. See e.g. Netratantra 1.29, 18.103 and Kaulajñannanirnaya 5.31 (and passim). At two instances in the Hațhapradīpikā and one in the Sivasamhitā the eight classical siddhis are called aiśvaryas (Hațhapradīpikā 3.7, 3.126, Śivasaṃhitā 3.58; cf. Yogasūtrabhāṣya ad 3.26). In the Amanaskayoga $(1.67,2.8)$ and Matsyendrasamhita $(8.60,8.65,21.4)$, two texts which do not teach hathayoga but which are closely related to the hațayoga tradition, the eight powers of anima and so forth are called siddhis.

${ }_{17}$ Dattātreyayogaśāstra 135.

18 Dattātreyayogaśāstra 157. 
dhi associated with the practice of hațayoga, but it will also demonstrate the two opposing attitudes towards siddhi evinced by the corpus. The Amrtasiddhi is almost certainly the oldest text on hathayoga, dating to the twelfth or perhaps eleventh century $\mathrm{CE}$, and it is exemplary of the attitude towards siddhis of the mumukșu, the seeker of liberation. The Śivasamhitā, which can be dated to the fourteenth or fifteenth centuries, is one of the youngest texts in the corpus and teaches hathayoga for the bubhukșu, the seeker of supernatural experience.

\section{SIDDHI IN THE AMRTASIDDHI}

The sectarian origins of the Amrtasiddhi are unclear. In its colophons it is ascribed to either Mādhavacandra or Avadhūtacandra and is said to represent the teachings of Virūpākșa. Although it has been claimed that this means that the text was produced by the Nàtha sampradaya on the grounds that Virūpākșa was a 'Nātha Siddha', ${ }^{19}$ this is unlikely, not least because the text predates the appearance of a Nātha sampradaya by several centuries ${ }^{20}$ and possibly also the life of its alleged founder, Gorakșa. ${ }^{21}$ External evidence suggest that the Amrtasiddhi may have been produced by forerunners of the Dasnāmi Saṃnyāsīs. ${ }^{22}$

${ }^{19}$ Kurtis R. Schaeffer, "The Attainment of Immortality: from Nāthas in India to Buddhists in Tibet." Journal of Indian Philosophy 30 (2002): 515-533. I enclose the phrase 'Nātha Siddha' within quotation marks because it is not to be found in premodern Indic literature.

20 The earliest example that I have found of the word 'Nātha' being used to describe a sampradaya of yogis is in a manuscript from Jodhpur of a text called the $\bar{A}$ deśapadavyākhyā. The manuscript appears to have been written in the early part of the nineteenth century, when the Nāthas had a brief period of influence over the Jodhpur court. The c.1700 Siddhasiddhäntapaddhati mentions nātha as one of five yogi lineages (5.43). The earliest reference to yogis being divided into twelve panths, an important (if only nominal) feature of Nātha identity to this day, is in a $v \bar{a} r$ written by Bhāì Gurdās in 1604 (Vāran̉ Bhāì Gurdās 8.13).

${ }^{21}$ The earliest datable reference to Gorakșa is in the Amrtakanikodyotanibandha, a sub-commentary on the Āryamañjuśrinnamasamgìti (p.202, 1.18) of Vibhūticandra, who flourished in the first half of the thirteenth century (Stearns 1996). I am grateful to Professor Harunaga Isaacson for drawing my attention to this reference.

${ }^{22}$ Siva as Virūpākșa was the tutelary deity of the first rulers of Vijayānagara, who in the fourteenth century patronised an advaita matha at Śrngeri which later became one of the first Dasnāmī Samnnyāsī monastic institutions. The Vijayānagara monarchs had earlier had Kālāmukha gurus who may have introduced them to the cult of Virūpākșa. (Matthew Clark, The Daśanāmì-Samnyāsīs: The Integration of Ascetic Lineages into an Order [Leiden: Brill, 2006], 198). 19 verses from the Amrtasiddhi are 
The Amrtasiddhi's yoga involves mastering the breath, raising it upwards through three granthis, uniting bindu and rajas (the male and female physical essences) and accessing the amrta, the nectar of immortality, in the head. The yogi thus becomes liberated while living (jivanmukta) and can live for as long as he wants, until he decides to exit his body through the 'Gateway of Brahmā' (brahmadvāra) and go to final liberation (mahāmukti). The Amrtasiddhi makes no mention of Kundalinī nor of cakras.

The siddhis in the Amrtasiddhi are very much of the akalpita variety described in the Yogabija: they are signposts on the way to mahāsiddhi. In what follows, I shall describe the various benefits and powers that arise in the course of the practice of the Amrtasiddhi's yoga. The basis of the Amrtasiddhi's yoga is the three practices called mahāmudrā, mahäbandha and mahāvedha, and it is the first text to teach these important hațhayogic techniques. Mahāmudrā gets rid of impurities, nourishes the nādīs, steadies bindu and $n \bar{a} d a$, and kindles the digestive fire (11.6). No subsidiary benefits are said to result from the practice of mahäbandha, which reverses the natural downwards flow of the nādīs (12.8), nor from mahāvedha, which brings about the breath's piercing of the three knots and the opening of the Gateway of Brahmā. Knowledge of this triad of practices brings knowledge of the three worlds. The yogi becomes an omnipotent and omnipresent god and has the ability and entitlement to do what he wants (13.10-15).

There are four stages (avasthās) on the yogi's path: ärambha, ghața, paricaya and nispatti. When the yogi is established in his practice, but before he reaches the first stage, physical signs of progress start to appear as a result of the increasing mastery of the breath: the constituents of his body (dhätus) increase, he does not suffer disease and his body becomes firm and strong (viveka 14).

Once established in the ârambhāvasthā, the yogi hears various 'unstruck' (anāhata) sounds, his body shines, he develops great digestive fire and strength, and a fine intellect, and he becomes completely beautiful and fragrant (viveka 19). In the ghațāvasthā, his posture (äsana) becomes firm, knowledge (jñāna) arises, he becomes like a god, he is physically powerful, he knows the truth (tattva), he knows what is to be done (vidhi), indeed he knows everything; he behaves auspiciously, he is endowed with all auspicious signs and he is free

found in the Śivasaṃhitā, suggesting a link with the latter's Samnyāsī tradition (on which see p. $\mathbf{x x}$ ). 
from all faults; he hears the sound of a kettledrum (viveka 20). On attaining the paricaya $\bar{v}$ asth $\bar{a}$, the yogi's body becomes perfected. This results in his becoming indifferent to hot and cold, and free from fear, desire, greed, disease, old age, pain and sorrow (viveka 24). An auspicious sound arises, which is a sign that success (siddhi) is near at hand (viveka 25). As a result of the mastery of the breath achieved in the paricayāvasthā, external powers (bāhyasiddhis) of a more supernatural nature arise: the yogi can transport his body and gain entry to someone else's city, and he can see and hear distant objects (viveka 28). He attains omniscience (viveka 29). In the final stage, nișpattyavasth $\bar{a}$, when the breath pierces the knot of Rudra (rudragranthi) the sound of a large kettledrum is heard. Mahāsiddhi arises, which bestows jīvanmukti, liberation while living. All-knowing and all-seeing, his hearing, sight, bliss and knowledge are unimpeded. He is endowed with all powers (these are variously called aiśvaryas, gunas and siddhis). He cannot be burnt, drowned or harmed. Happy, he can create worlds, angry he can destroy them. He frightens the gods. Such siddha yogis can remain thus for hundreds of thousands of years (viveka 31). When finally he leaves his body by way of the 'Gateway of Brahmā' (brahmadvāra), the sweet sound of a vinna is heard (viveka 33).

\section{SidDHI IN THE ŚIVASAMHITĀ}

In contrast to the difficulty of locating the Amrtasiddhi within a specific tradition, internal and external evidence points to the Śivasam being the product of the orthodox tradition of the Sankarācāryas of Kanchi and Shringeri, a tradition which came to be incorporated within the Daśanāmī Saṃnyāsī samp pradāya. ${ }^{23}$

${ }^{23}$ The Śivasam hitā includes teachings influenced by both advaita Vedānta and Śrīvidyā, the latter a purified form of Southern Transmission Kaula Śaivism. These two traditions formed the doctrinal basis of the Śrnigerī mațha. The Śivasamhitā also borrows from and extensively paraphrases the Dattātreyayogaśāstra, a text which is the product of a tradition of Vaiṣnava yogis later incorporated within the Daśanāmī sampradāya. The Sivasamitat does not, however, borrow significantly from texts such as the Vivekamārtanda and Gorakșaśataka, which came to be associated with the Nātha sampradāya. 
Siddhi is first mentioned in the third pațala of the Sivasamhitā in verses redolent of the Amrtasiddhi. ${ }^{24}$ Purification of the nādīs, which is the result of assisted breath retention (sahita kumbhaka), gives the yogi a balanced body, a good smell and a good complexion, and makes him a receptacle for the nectar of the gods. He thus attains the first stage of yoga, the àrambhàvasthā (3.29-30). In the second stage, the ghațāvasth $\bar{a}$, the yogi has a strong digestive fire, eats well, is happy, has a beautiful body, is big-hearted and has great willpower and strength (3.33).

Interpolated in the description of the four avasthas is a passage on the things to be avoided or cultivated while practicing yoga (3.34a$44 \mathrm{~b}$ ), followed by a passage on breath retention (kumbhaka) which is a reworking of a similar passage in the Dattātreyayogaśästra. ${ }^{25}$ In the course of his mastering unassisted breath retention (kevala kumbhaka), ${ }^{26}$ the yogi first sweats, then trembles, then jumps about like a frog and finally moves about in the sky. When the yogi leaves the ground, he is known to have achieved mastery (siddhi) of the wind/ breath (3.46-48). The yogi should observe the rules of yoga until his sleep, feces and urine diminish. He is freed from disease and unhappiness. Sweat, slobber and worms, and imbalances of the three humors do not arise in his body. He can eat as much or as little as he likes. He obtains bhücarīsiddhi. ${ }^{27}$ Then, by means of prānāyāma, he destroys his past karma, attains the eight classical siddhis and becomes the lord of the three worlds (3.58). Once he can hold his breath for three ghatikās (72 minutes), he is sure to achieve complete success (sakalä siddhi) (3.59). This includes mastery of speech, the ability to go where he wants, long-distance vision and hearing, subtle sight and the powers of entering another's body, producing gold by smearing objects with his feces and urine, making things invisible and moving through space (3.60-61).

\footnotetext{
${ }^{24}$ The Śivasamhitā directly borrows 19 verses from the Amrtasiddhi. None is in the Sivasamhitä's third pațala but the latter's teachings on the four avasthās of yoga are derivative of those found in the Amrtasiddhi.

${ }^{25}$ Compare Śivasaṃitā 3.44c-52 with Dattātreyayogaśāstra 143-162 (the editio princeps of the Dattātreyayogaśästra is numbered by half-verses).

26 Assisted breath retention (sahita kumbhaka) involves particular methods of inhalation and exhalation, and holding the breath for specified lengths of time. Unassisted breath retention (kevala kumbhaka) has no such strictures and can be performed comfortably for as long as the yogi wishes.

${ }_{27}$ The ability to move like animals which are hard to catch when one claps one's hands (3.52).
} 
When, in the course of his progress from the ghatāvastha to the paricayāvasthā, the yogi develops the ability to hold his breath for three hours, he can then perform pratyāhāra and achieve mastery over his sense organs (3.64-65). Through further breath retention ${ }^{28}$ the yogi can support himself on one thumb. Once he has reached the paricay $\bar{a} v a s t h \bar{a}$ the yogi can practice the five elemental dhärañass on five locations in the body. He thus gains the siddhis of earth and the other elements and does not die even in a hundred deaths of Brahmā (3.72-75). In the course of his practice the yogi finally attains the nispattyavasth $\bar{a}$, thereby breaking free of karma and drinking the nectar of immortality (amrta). He can enter samädhi at will (3.76-77).

This passage on the four avasthās is followed by one describing various ways of inhaling air and, by means of an unnamed khecarimudrā, drinking the liquid from the moon (3.80-95). These result in the yogi defeating disease, fatigue, old age and death, obtaining the powers of long-distance hearing and sight, becoming Bhairava, obtaining the eight classical siddhis, conquering the elements, becoming a second god of love, becoming neither hungry nor thirsty, neither sleeping nor fainting, being able to move where he wishes, not being reborn and enjoying himself in the company of the gods.

Four āsanas are taught next. They are somewhat easier methods of obtaining siddhi than the extended prānayamas already taught: siddhäsana brings about the niṣpattyavastha and the yogi can use it to reach his ultimate destination (3.99); padmāsana gets rid of all diseases (3.105) and by correctly inhaling while sitting in padmāsana, the yogi becomes liberated (3.107); paścimottānāsana removes fatigue and kindles the digestive fire (3.109) and those who practice it attain complete success (sarvasiddhi); svastikäsana prevents disease and grants mastery of the wind.

The Śivasamnhitā's fourth pațala teaches hațhayogic mudrās. Yonimudrā (4.2-19) grants the powers of cheating and conquering death (kālavañcana and mrtyumjaya), mastery of speech and the ability to go where one wants. In the description of the mahāmudrā which follows (4.25-36), three and a half verses from the Amrtasiddhi's description of mahāmudrā are incorporated, including, at 4.32, the Amrtasiddhi's description of the siddhis which arise from its practice (on which see above). To these are added perfect physical beauty, the

${ }^{28}$ I.e. for a duration of eight dandas (3.67). The length of a danda is unclear. 
destruction of old age and death, the achievement of desired goals, happiness and the conquest of the senses (4.33). Next is mahäbandha (4.37-42). This passage incorporates one verse from the Amrtasiddhi, in which the mechanics of the practice are taught. Unlike the Amrtasiddhi, however, the Śivasamhitā includes verses describing the benefits of the practice (4.41-42): it nourishes the body, makes the skeleton strong, fills the yogi's heart and allows him to achieve all that he wants. The practical details of the mahàvedha of the Sivasamhitā are somewhat different from those of the Amrtasiddhi's, but like that of the latter it is said to enable the yogi to use the breath to pierce the knots in the central channel and open the Gateway of Brahmā. In both the Amrtasiddhi and the Śivasamhitā, the gods situated along the central channel are said to tremble thanks to the rising wind; the Śivasamhitā adds (4.46) that Kunḍalinī comes to rest at Kailāsa. The Sivasamhitā further adds that the yogi thereby achieves the siddhi of wind, which gets rid of old age and death, and that by regular practice of mahāvedha, mahāmudrā and mahäbandha he is sure to conquer death within six months (4.48). Khecarimudrā (4.51-4.59) brings about perfection of the body (vigrahasiddhi), enables the yogi to enjoy divine delights before being born in a good family and to reach the ultimate destination. Jâlandharabandha (4.60-4.63), by diverting the nectar of immortality from the fire at the navel, makes the yogi immortal. Mülabandha (4.64-68) destroys old age and death, and enables the yogi to conquer the wind, thereby rising up from the earth. By means of vipraritakaranī (4.69-71) the yogi conquers death. Udyannabandha destroys sorrows, brings mastery of the wind, perfection of the body and elimination of disease. Vajrolimudrā and its variants amaroli and sahajoli (4.78-4.104) enable the yogi to achieve mokșa even if he indulges his senses, in particular by having sex. Śakticālana (4.105110) destroys diseases, brings perfection of the body, bestows the eight classical siddhis and removes the fear of death. In concluding the chapter on mudrās, it is said that each of them, when mastered, bestows siddhi (4.111).

The Śivasamhitā's fifth and final patala teaches practices which are more subtle than the hathayogic techniques taught in the third and fourth patalas. At 5.36-46 the yogi is instructed to use his fingers to block his ears, eyes, nostrils and mouth and then listen to the internal sounds. A progression of sounds arises, absorption in which results in laya. 5.53-59 teaches an obscure practice which involves pressing the 
two vijñanna nādīis, ${ }^{29}$ resulting in mastery of the breath, the destruction of sins, the eight classical siddhis and the ability to wander freely about the three worlds. There follow visualizations based in part on some of the samyamas taught in the Yogasütra's vibhütipäda and which are similarly said to result in various siddhis. Concentration on the adam's apple, for example, is said to get rid of hunger and thirst (5.60-71; cf. Yogasūtra 3.30).

At 5.77-207, there is a long and detailed description of various locations in the subtle body, including the seven lotuses, complete with associated bijamantras, colors, deities and siddhas. Meditation on these, which is said to be rājayoga, results in a plethora of siddhis. To give just one example, meditation on the mülädhära lotus results in the ability to leave the ground like a frog (dardurisiddhi), a very beautiful body, increased digestive fire, good health, sharp faculties, knowledge of the past and future, knowledge of all speech and of all sacred texts and their secret doctrines, the goddess of speech dancing in the yogi's mouth, mantra-siddhi, the immediate destruction of all sins, the attainment of whatever is wanted and, eventually, complete (sakalā) siddhi (5.87-101). And that is just the first lotus. Finally, at 5.232-252, mantrayoga is taught. By means of increasing numbers of repetitions of a three-syllabled mantra (from 100,00 to 10,000,000), together with ritual fire-offerings, the yogi summons the goddess Tripurabhairavi and attains another bewildering array of siddhis, including the subjugation of all beings, mortal and divine, and culminating in the attainment of the state of Siva.

There is thus a marked difference between the treatment of siddhi in the Amrtasiddhi and its treatment in the Sivasamhitā. The goal of the Amrtasiddhi is the great siddhi, liberation, and the lesser siddhis which arrive along the way are signs of mastery of yoga's techniques and progress through its stages. The attitude towards siddhis implied by the Amrtasiddhi is akin to that evinced by the Dattätreyayogaśästra and Yogabija paraphrased above. The redactor of the Sivasamnitā incorporated much of the Amrtasiddhi within the text, both by borrowing verses wholesale and paraphrasing them, but added a Kaula slant to the Amrtasiddhi's treatment of siddhi. Siddhis are everywhere in the Sivasamhitā. Where it borrows from other works on hathayoga, such as in its descriptions of the four avasthās and three mudrās

29 The location of these nādīs is obscure. 
taught in the Amrtasiddhi, it adds several extra siddhis, to the extent that it becomes unclear whether they are kalpitā or akalpitā. In other practices, particularly the typically Kaula visualizations and mantra techniques taught in its fifth upadeśa, wildly supernatural siddhis take centre stage. Techniques of obtaining siddhis taught in the Yogasütra are also found in the Śivasamphitā, but not the Yogasūtra's admonition that siddhis, even though they are signs of awakening, are hindrances to samādhi.

The Sivasamhitā's promotion of siddhis is concomitant with its Kaula bubhukșu heritage. The most explicitly Kaula text in the early corpus of hațhayogic texts, the Khecarividyā, takes a similar position. At the end of its first patala, khecarimudrā is said to bestow a wide range of siddhis-in fact it is said to bestow all the siddhis that exist in the three worlds-including ones not mentioned elsewhere in the hathayogic corpus but common in Kaula works (where they are usually kalpitā, 'intentional') such as finding buried treasure, entering subterranean realms, controlling the earth, mastering alchemy, ${ }^{30}$ winning power over male and female genies, and procuring magical sandals, swords and elixirs. ${ }^{31}$ In the second patala, accessing the different stores of amrta in the body is said to make the whole gamut of siddhis available to the yogi. ${ }^{32}$ In the Khecarividya's fourth patala various herbal preparations are said to bestow various physical benefits, in particular rejuvenation.

\footnotetext{
${ }^{30}$ Pace David Gordon White, The Alchemical Body: Siddha Traditions in Medieval India (Chicago : University of Chicago Press, 1996) who argues (p. 10) that "if they were not one and the same people, [hathayogis and alchemists] were at least closely linked in their practice", the Khecarividya $\bar{a}$ 's assertion that khecarimudrā can give the yogi the siddhi of alchemy suggests that the practitioners of hathayoga and alchemy were quite distinct. This is also implied by the Khecarividyä's deliberate trumping of alchemical practice with its technique of aingamardana [Khecarividya 2.72-79, on which see Mallinson, The Khecarīvidyā of Ādinātha, 220 n.328). Other works also teach that the techniques of hathayoga can bestow alchemical siddhi. In both the Sivasamnitā (3.61) and Dattätreyayogaśāstra (197) it is said that the yogi in the ghat $\bar{a} v a s t h \bar{a}$ can turn objects into gold by smearing them with his faeces and urine. Sivasamhitā 5.112 teaches that meditation on the Manipūra lotus gives the power to create gold. In the Dattätreyayogaśästra, alchemy is said to be one of the obstacles to success in the practice of yoga (103).

${ }^{31}$ Khecarīvidya $\bar{a} 1.65-77$. The Kaula siddhis are listed at 1.68 and $1.75 \mathrm{c}-1.76 \mathrm{~b}$; see the notes ad loc. for parallels in Kaula works, including the Matsyendrasamhitā.

${ }^{32}$ Khecarìvidya $2.1-69$.
} 


\section{Siddhi in Classical Hațhayoga}

The Hațapradīpika is a compilation of earlier works on hața and other methods of yoga whose teachings are synthesised into a new classical hathayoga consisting of four types of practice: āsana, kumbhaka, mudrā and nādānusandhāna (1.56). The Hațhapradīpikā became hathayoga's locus classicus and its teachings formed the basis of most subsequent texts on the subject. Its combination of verses from various different texts is remarkable for its inclusivity, even if this does lead to some inconsistencies. In spite of its inclusivity, however, the Hathapradīpika represents a successful attempt to appropriate hathayoga by a siddha tradition which traced its lineage through Kaula teachers such as Matsyendra and Gorakșa, and which was, at the time of the Hathapradipikä's composition, starting to coalesce into the order which would several centuries later become known as that of the Nāthas. It is striking that the Hațhapradīpikā, despite borrowing over 60 verses from texts associated with orders of yogis that were, at the time of its composition, coalescing into the Daśanāmī and Rāmānandī sampradāyas, makes no mention of their legendary teachers, in particular Dattātreya, from whose yogaśāstra the Hațhapradīpikā borrows 40 verses. $^{33}$

The hathayogic tradition represented by the Amrtasiddhi and Dattātreyayogaśästra is likely, at least on textual evidence, to predate that linked with Matsyendra and Gorakșa. The former teaches a yoga that uses the breath to raise bindu upwards along the central channel, piercing three knots along the way. The latter superimposes Kundalini and the cakras or padmas onto this system. ${ }^{34}$ This superimposition results in some problems. The aim of the bindu-oriented yoga is to keep bindu in the head; the Kundalini-based systems want to flood the body with amrta, bindu's analogue. The primacy of the bindu paradigm can be inferred from its being found in the systems of yoga taught in the Amrtasiddhi and Dattātreyayogaśästra in which Kuṇạa-

${ }^{33}$ Kapila, who is the first siddha to be associated with hathayoga (Dattätreyayogaśästra 57) is also not mentioned in the Hațapradīpikā. Vasișța is mentioned once, at 1.18 , in the context of āsana. The rivalry between the yogi followers of Dattātreya and those of Gorakșa persisted until the 17th or 18th centuries when they were reconciled, a reconciliation legitimized in texts such as the Gorakșasiddhāntasamgraha and Yogisampradāyāvișkrti.

34 These two paradigms of the practice of hathayoga are summarized at Śärngadharapaddhati 4365a-4371b; for a translation and commentary, see Mallinson 28-30. 
linī plays no part. ${ }^{35}$ Every comprehensive text on hathayoga which teaches the raising of Kundalinī also tries, with mixed results, to accommodate bindu-oriented yoga. ${ }^{36}$

The Vivekamairtanda, perhaps the earliest text to impose the subtle physiology of the Kaula Western Transmission onto the bindu system, does not impose its bubhukșu approach to siddhis. The latter is only to be found in works such as the Khecarividya and the Sivasamhitā, which postdate the Vivekamārtanda by approximately a century. The

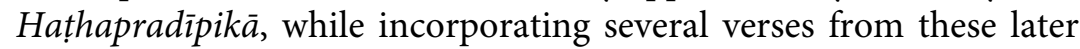
works, reflects the mumukșu attitude towards siddhis. It relegates sid$d$ is to a place of even less importance than that which they hold in the Vivekamārtanda. Physical practices such as äsana, kumbhaka and the șatkarmas have, unsurprisingly, physical benefits as well as benefits which further the yogi's progress towards mokșa, ${ }^{37}$ but supernatural siddhis are rare. A handful are mentioned in the context of the mudrās taught in the third upadeśa, ${ }^{38}$ but, as in the Vivekamārtanda, the more outlandishly supernatural powers found in other tantric and yogic works, such as bhīcarisiddhi or the abilities to fly, to enter someone else's body (parakāyapraveśana) ${ }^{39}$ or to cast off one's own body at will (utkränti) ${ }^{40}$ are nowhere to be found. The aim of the Hathapradīpikä's mudrās, which any one of them is able to effect singly, is mahāsiddhi (3.124).

The Hathapradipikä's attitude towards siddhi is in keeping with hathayoga's rejection of the exclusivity, complexity and esotericism of

\footnotetext{
${ }^{35}$ Kundalinīi is not mentioned in the Amrtasiddhi; she is mentioned in passing at Dattātreyayogaśāstra 213.

${ }_{36}$ There are two texts which present Kundalinī-based systems of hathayoga almost entirely free of any mention of bindu: the Khecarividya and the Goraksaśataka. The former is among the later texts of the corpus since it mentions the Vivekamärtanda (1.14). The latter (on which see James Mallinson, "The Original Gorakșaśataka," in Yoga in Practice, edited by David Gordon White (Princeton: Princeton University Press, forthcoming 2011), can be tentatively dated to $1400 \mathrm{CE}$ but the similarities between its yoga techniques and those of the Jñāneśvarī suggest that they were well established by the time of its composition. They might thus represent a Kunḍalinī-based hațhayoga tradition independent of the bindu-oriented tradition.

${ }^{37}$ E.g. bhastrika kumbhaka's removal of the knot of phlegm (kapha) which blocks the mouth of the brahmanādi thereby enabling Kunḍalini to pierce the three granthis (Hațhapradīpikā 2.66c-67b = Gorakșaśataka 48).

${ }^{38}$ See Hathapradīpikā 3.49, 3.94, 3.98.

39 On parakāyapraveśana see Mallinson, The Khecarīvidyā of Ādinātha, 237 n. 439 .

${ }^{40}$ On utkrānti see ibid.: 238 n.448.
} 
tantra. Gone are tantra's mantras, manḍalas, initiations and visualizations (all methods of attaining kalpità siddhis in their own right); gone too are the associated kalpitā siddhis. ${ }^{41}$

\section{Conclusion}

Like much of its technical vocabulary and soteriological framework, hathayoga shares its siddhis with other tantric and yogic systems. Except for some of the lesser physical benefits associated with particular physical practices, ${ }^{42}$ all the hathayogic siddhis can be obtained by other types of yoga. ${ }^{43}$ Many of them can also be obtained by the technique of samyama taught in the Yogasütra's vibhütipäda. Unlike the latter, however, classical hațhayoga as taught in the Hațhapradīpika and most of the earlier texts of the hathayogic corpus does not prescribe direct means to intentional siddhis; its siddhis arise unintentionally as by-products of techniques which lead to mahassiddhi, the great siddhi, namely liberation while living.

Thus, in contrast to what one might expect, the Hathapradipika and the majority of the texts of early hathayoga are less concerned with the supernatural than the Yogasūtra (and many tantric works), since they proscribe intentional striving after siddhis and make no reference to occult siddhis such as parakāyapraveśana and utkrānti which are taught, or at least mentioned, in the Yogasütra and Kaulainfluenced hațhayogic works such as the Khecarìvidyā and Sivasamhitā. $^{44}$

${ }^{41}$ Particularly noteworthy is the absence of cakras or padmas in the Hathapradīpikä's subtle physiology, in spite of Kundalinī's primacy in the text. Perhaps, in his quest for inclusivity, amidst a plethora of different cakra systems (the six/seven padma system of the Paścimāmnāya was yet to achieve hegemony) Svātmārāma did not want to alienate any groups by prioritising one particular system.

${ }^{42}$ See, for example, the benefits associated with the kumbhakas and șațkarmas taught in the Hathapradīpikā's second upadeśa.

${ }^{43}$ See, for example, the Dattātreyayogaśästra, in which the siddhis obtained by means of mantra $a^{\circ}$, laya $a^{\circ}$ and rajjayoga are very similar to those obtained by hathayoga, or the Amanaskayoga, which roundly condemns the practices of hațayoga (see in particular Amanaskayoga 2.31 and 2.42), but whose non-physical yoga is said to achieve a wide range of siddhis similar to those found in hațhayogic texts.

${ }^{44}$ Parakāyapraveśana and utkrānti are the results of particular samyamas taught at Yogasūtra 2.38-39. Parakāyapraveśana is mentioned as a siddhi at Śivasamhitā 3.60 and 5.111. Utkrānti is taught at Khecarīvidya 3.48-53. Intentional siddhis and practices such as parakāyapraveśana and utkrānti do resurface in later formulations 
These Kaula-influenced texts were bubhukșu blips in hațayoga's otherwise smooth progress towards becoming the dominant method of mumukșu yoga, as evinced by its orthodox canonization in the Yoga Upanișads in the seventeenth and eighteenth centuries. Alternatively, we might view these curious and wonderful works, together with their mumukșu counterparts, as unintentional siddhis manifesting on hațayoga's own path to mahāsiddhi.

\section{REFERENCES}

\section{Manuscripts Consulted}

Amṛtasiddhi of Virūpākṣanātha. Maharaja Mansingh Pustak Prakash, Jodhpur, Acc. Nos. 1242-1243.

Ādeśapadavyākhyā. Maharaja Mansingh Pustak Prakash, Jodhpur, Acc. No. 1285(B).

Gorakșaśataka. Government Oriental Manuscripts Library, Madras, MS No. R 7874. ${ }^{45}$

Dattātreyayogaśāstra. Maharaja Mansingh Pustak Prakash, Jodhpur, Acc. Nos. 19361937.

Matsyendrasamhitā. The Wellcome Institute for the History of Medicine, London. MS Sansk. $\beta$ 1115; Maharaja Mansingh Pustak Prakash, Jodhpur. MSS No. 1782, 1784.

Yogabija. Maharaja Mansingh Pustak Prakash, Jodhpur, MSS Nos. 1854-1857.

Vivekamärtaṇda of Gorakșadeva. Oriental Institute of Baroda Library. Acc. No. $4110 .{ }^{46}$

\section{Primary Sources}

Amanaskayoga, ed. Jason Birch. Unpublished work in progress. Amaraughaprabodha, of Gorakșanātha, ed. K. Mallik in MALLIK 1954.

Amaraughaśāsana, of Gorakșanātha, ed. Pt. Mukund Rām Saastrī. Kashmir Series of Texts and Studies 20. Srinagar. 1918.

of hațayoga: see, for example, Jogpradīpakā 797-804 which teaches parakāyapraveśana, Siddhasiddhāntapaddhati 2.10-25 which describes the rewards to be obtained from physical practices relating to each of the sixteen $\bar{a} d h \bar{a} r a s$ and ibid. 5.38 where parakāyapraveśana is included in a list of siddhis.

${ }^{45} \mathrm{I}$ am very grateful to $\mathrm{M}$. Christian Bouy for providing me with a copy of this manuscript. This Gorakșaśataka is a different text from that of the same name edited by NOWOTNY, which I refer to in this paper as the "Nowotny Gorakșaśataka". The latter was originally known as the Vivekamärtanda, which is how I refer to it in this paper, and when referring to verses from the Vivekamärtanda I cite the verse numbering as found in its oldest manuscript, which was copied in $1477 \mathrm{CE}$, rather than Nowotny's edition of the Gorakșaśataka, which represents a later recension. On the Vivekamārtand da and Gorakșaśataka, see Mallinson, "The Original Gorakșaśataka," and Mallinson, The Khecarìvidyā of Ādinātha, 166 n.9.

${ }^{46}$ See note 45. 
Āryamañjuśrīnāmasamgîti with Amrtakanikāțippanī by Bhikṣu Raviśrījñāna and Amrtakanikodyotanibandha of Vibhūticandra, ed. B. Lal. Sarnath: Central Institute of Higher Tibetan Studies. 1994.

Khecarìvidyā. James Mallinson. The Khecarìvidyā of Ādinātha. A critical edition and annotated translation of an early text of hathayoga. London: Routledge, 2007..

Gorakșaśataka, ed. F. Nowotny: Das Gorakșaśataka, Köln 1976 (Dokumente der Geistesgeschichte). ${ }^{47}$

Gheraṇdasamhitā, ed. and tr. J. Mallinson. New York: YogaVidya.com. 2004.

Jogpradīpakā of Jayatarāma, ed. M.L. Gharote. Jodhpur: Rajasthan Oriental Research Institute. 1999

(Śrī)-Jñāneśvarī of Jñānadeva, ed. G.S. Nanadīkar. 5 vols. Mumbai: Prakāś Gopāl Naṇadikkar. 2001.

Dattātreyayogaśástra, ed. Brahmamitra Avasthī. Delhi: Svāmī Keśavānand Yogasaṃsthān. 1982.

Mārkaṇdeyapurāna, ed. K.M. Banerjea. Calcutta: Bishop's College Press. 1862.

Yogabīja, ed. Rām Lāl Śrīvāstav. Gorakhpur: Śrī Gorakhnāth Mandir. 1982.

Yogasūtra of Patañjali with the commentaries (Bhāșya, Tattvavaiśāradī, and Yogavārttikā) of Vyāsa, Vācaspatimiśra, and Vijñānabhikșu, ed. Nārāyaṇa Miśra. Benares: Bhāratīya Vidyā Prakāśan. 1971.

Vārāin Bhāì Gurdās, ed. Jodh Singh. Patiala: Vision \& Venture. 1998.

Śārngadharapaddhati, ed. Peter Peterson. Bombay: Government Central Book Depot. 1888.

Śivasaṃitāa, ed. and tr. J. Mallinson. New York: YogaVidya.com.

Siddhasiddhāntapaddhati of Gorakșanātha, ed. M.L. Gharote and G.K. Pai. Lonavla: Lonavla Yoga Institute. 2005.

Hațhapradīpikā of Svātmārāma, ed. Svāmī Digambarjī and Dr Pītambar Jhā. Lonavla: Kaivalyadhām S.M.Y.M. Samiti. 1970.

Hațharatnāvalī, ed. M.L.Gharote, P.Devnath, V.K.Jha. Lonavla: Lonavla Yoga Institute. 2002.

Secondary Sources

Bouy, Christian. Les Nātha-Yogin et les Upanișads. Paris: Diffusion de Boccard, 1994.

Clark, Matthew. The Daśanāmì-Samnnyāsīs: The Integration of Ascetic Lineages into an Order. Leiden: Brill, 2006.

Hara, Minoru. "Pāśupata and Yoga: Pāśupatasūtra 2.32 and Yogasūtra 3.37." Asiatische Studien 53, no. 3 (1999): 593-608 .

Kiehnle, Catherine. "The Secret of the Nāths: The Ascent of Kundalinī according to Jñāneśvarī 6.151-328.” Bulletin des Études Indiennes 22-23 (2005): 447-494.

Mallinson, James. The Khecarīvidyā of Ādinātha. A critical edition and annotated translation of an early text of hathayoga. London: Routledge, 2007.

"The Original Gorakșaśataka. " In Yoga in Practice, edited by David Gordon White. Princeton: Princeton University Press, forthcoming 2011.

Mallinson, James. Yoga and Yogis: The Texts, Techniques and Practitioners of Traditional Hathayoga (forthcoming).

Sanderson, Alexis.. "Śaivism and the Tantric Traditions." In The World's Religions, edited by S. Sutherland, L. Houlden, P. Clarke and F. Hardy, 660-704. London: Routledge, 1988.

${ }^{47}$ See note 45 . 
Schaeffer, Kurtis R. "The Attainment of Immortality: from Nāthas in India to Buddhists in Tibet." Journal of Indian Philosophy 30 (2002): 515-533.

Stearns, Cyrus. "The Life and Tibetan Legacy of the Indian Mahāpaṇịta Vibhūticandra." The Journal of the International Association of Buddhist Studies 19 (1996): 127-171.

White, David Gordon. The Alchemical Body: Siddha Traditions in Medieval India. Chicago: University of Chicago Press. 1996. 